\title{
BESTIAL OR HUMAN LUSTS? THE REPRESENTATION OF THE MATRON AND HER SEXUALITY IN APULEIUS, METAMORPHOSES 10.19.3-22.5*
}

\author{
Susan Haskins \\ University of Pretoria
}

\begin{abstract}
The bestiality episode in Apuleius' Metamorphoses (10.19.3-22.5) is unique in extant Latin literature and has generated interest among scholars as to why Apuleius included it. These studies have centred on the main character, Lucius, and the relationship between this episode and the broader theme of animal/ human duality throughout the novel. However, the function of the woman in the episode has tended to be subsumed into these discussions. The question of whether or not the woman of the bestiality episode is exercising bestial or human lusts is important in interpreting the women in the novel in general. She therefore needs a study devoted to her and the representation of her sexuality. This study will show that, in her case, her lust for an ass is human rather than bestial, and this illustrates the wider issues in the novel concerning the insatiability of female sexual nature and the dangers (from the male point of view) of female control over their own sexuality.
\end{abstract}

\section{Introduction}

The sexual encounter between a woman, identified only as a matron, and the hero Lucius in the form of an ass, in Apuleius' Metamorphoses $(10.19 .3-22.5),{ }^{1}$ is unique. $^{2}$ It is the only description in extant Latin

\footnotetext{
* This article began as a paper that was given at the Celtic Conference in Classics, University of Edinburgh, 28-31 July 2010. I would like to thank Dr Koos Kritzinger, Prof. Gerhard Swart and the journal referees and editors for their many helpful comments on this paper. Any remaining errors are my own.

${ }^{1}$ Hereafter Ps.-Lucian's Onos will be abbreviated in references as On. and Apuleius' Metamorphoses will be abbreviated as Met. The text of On. is from the Loeb edition by MacLeod 1967 and that of the Met. from Oxford edition by Zimmerman 2012.
}

DOI 10.15731/AClass.057.03 
literature of a sexual encounter in which a human willingly copulates with an animal, ${ }^{3}$ or in other words, commits an act of bestiality. The uniqueness of this episode has naturally excited the interest of scholars as to why Apuleius would choose to include it. ${ }^{4}$ There is an obvious parallel between Lucius' dual and ambiguous nature as both man and ass, and the sexual encounter, involving Lucius, between a human and an ass. This has led scholars to focus on Lucius and the theme of human/animal duality in their investigations. They conclude that the act of bestiality reflects on and emphasises the bestial characteristics of other characters, episodes or themes, especially in relation to Lucius' metaphorical journey of selfdiscovery. ${ }^{5}$ In particular, the sexuality of the act of bestiality, and its participants, is usually discussed as part of a theme of unrestrainable, and therefore animalistic, sexual depravity in the novel. ${ }^{6}$ However, no study has been devoted to the matron and her sexuality to discover if it is indeed

\footnotetext{
${ }^{2}$ See Zimmerman 2000:265. However, mixed couplings seem to be a theme of the Metamorphoses. See the discussion of Lisa Hughes's premise of miscegenation in James 2014:325-26 and also Shelton 2005:323 n. 52.

${ }^{3}$ Except for a corresponding episode in the Greek text, the Onos (50-52), and a recently discovered Greek papyrus (P.Oxy. LXX.4762) containing a fragment of a sexual penetration scene between a woman and an ass, which may or may not belong to the same tradition (see May 2009), all other descriptions of acts of bestiality occur in mythology. See Robson 1997 on bestiality in Greek myths; Robson's work is the only existing scholarship on bestiality in Greek and Roman literature in general. Juvenal (6.334) writes of a woman taking an ass as a lover as a last resort. Suetonius (Ner. 12) and Martial (Spect. 5) both mention acts of bestiality in the amphitheatre, but none of these writers describe the actual act.

${ }^{4}$ Despite the likelihood that Apuleius took the idea of the bestiality episode from a similar Greek text, along with many other story elements, the changes he made to them were broad enough (cf. note 11) that the presence of this episode in the Greek text is not sufficient reason to explain its inclusion by Apuleius in the Metamorphoses.

5 Schlam 1992:53, 73, 103, 105; Shumate 1996:62, 65-67, 107-19; PucciniDelbey 2003:108-10; Shelton 2005:311-17, 322-24, 326-27. See also Zimmerman 2000:264-92, who mentions the conclusions of others in her commentary on Book 10.

6 Cooper 1980:446; Puccini-Delbey 2003:108-10, 111, 113, 159. See also Frangoulidis 2001:159, who discusses the bestiality episode as part of a discussion on 'marriage' themes in the Metamorphoses. The pursuit of this theme is especially popular due to the episode's similarity to earlier sex scenes between Lucius and the slave-girl Photis. See Garson 1977/78:37-39; Schlam 1992:37, 72-73.
} 
her main function to reflect on and emphasise bestial aspects in the novel, ${ }^{7}$ or if she has some other role to play. Considering the episode's similarity to the description of the sexual encounter between Lucius and Photis, as well as the many women in the novel who are involved in, or are planning, socially unacceptable sexual acts, ${ }^{8}$ her episode does indeed seem to hold a great deal of importance for the reading and interpretation of other women in the novel, as well as Lucius himself. It is therefore vital that the episode be thoroughly examined with the focus on the portrayal of the matron, especially her sexuality, to fully understand her functions.

Such an in-depth investigation will be accomplished by making a literary analysis of the ways in which Apuleius depicts the matron and constructs her sexuality. This requires an examination, not only of the depiction of her physical body and sex acts, but also of her emotional stimuli, social position, and the expectations attached to that position. The analysis will be greatly facilitated by comparing and contrasting Apuleius' portrayal of her with that of a woman in a similar episode in Loukios or the

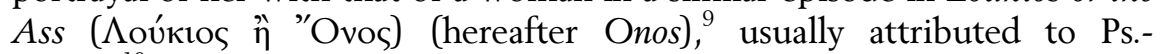
Lucian. ${ }^{10}$ The nature of the Greek text's relationship to the Metamorphoses is a matter of debate. ${ }^{11}$ Nevertheless, it can be agreed that the Metamorphoses and the Onos have the same basic plot (with the exception of the

\footnotetext{
${ }^{7}$ The closest such study is one by Shelton (2005) on the act of bestiality nearly forced upon a condemned murderess (Met. 10.23.2), and how this episode can be used to understand the inversion of the natural hierarchy in the novel by women. However, Shelton's discussion stems from an entirely different woman and set of circumstances, which mean that the conclusions she draws about bestiality cannot be applied to the matron. However, she does note some intratextual links between the matron and the murderess which deserve further study (Shelton 2005:323-24).

${ }^{8}$ For adulteresses, see Met. 2.29.5-6 (also 2.27.4-7); 9.5-7; 9.14.2-16.3, 22.1-23.3, 26.1-27.2; and 9.17-20; 9.23.4-25.6. For witches practicing magic to ensnare men, see Met. 1.7.7-8.6; 2.5.2-8; 3.16.1-18.4, 21.

${ }_{9}$ The Byzantine scholar Photius (Bibl. 129) believed that the Onos was an

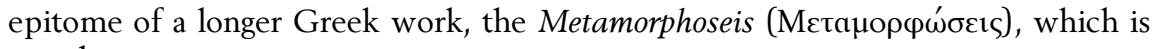
now lost to us.

10 See Perry 1967:223-25 and later Mason 1978:2-3 for the debate over authorship. In their translations, MacLeod 1967 and Sullivan 1989 attribute the work to Ps-Lucian.

${ }^{11}$ However, it is generally believed that Apuleius took his basic story from the Greek (cf. note 9), and by interpreting rather than translating, created his own unique work, adding in many original episodes and self-contained stories (Perry 1967:212, 217-18, 243-45; Van Thiel 1971; Mason 1978:3-6).
} 
ending). ${ }^{12}$ This includes an almost identical bestiality episode, in terms of sequence of events and basic story components. On the other hand, there are also differences in some of the wording, the tone, emphasis and length of the episode between the two texts. Reading the basic story components of the two texts in conjunction brings Apuleius' focus points into sharp relief and allows a more subtle reading than could be possible reading the Metamorphoses in isolation. This examination will show that the matron is not just a human foil to Lucius as ass, whose purpose is to highlight issues of animality. In fact, this will be found to be one of her lesser functions. Instead, she plays an important part of themes of insatiable female sexual natures and female sexual control.

\section{Identifying and describing the female}

The first element of the female's portrayal which will be examined is the terms used to socially identify and define her throughout the passage. In neither text is the woman ever given a name. However, when comparing them it can be seen that Apuleius' choice of identifying terms is a vital element of her portrayal. In the Onos, Ps.-Lucian refers to her mainly as $\dot{\eta}$ ruví (On. 50, 51: 6 times). Гuví is a fairly generic word for 'woman' or 'wife,', ${ }^{13}$ with no particular status connotations, and one that can also be used to denote the female of the species. ${ }^{14}$ While it is unlikely that this woman is unmarried, the text is not explicit on this point. Only once is the woman not referred to as $\dot{\eta}$ ruví. As the ass mentions how much he is looking forward to the sexual encounter because of her looks, he calls her

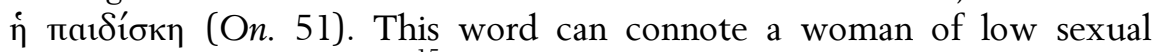
status, such as a courtesan. ${ }^{15}$ In the eyes of the ass, her sexual choices have placed her in this category.

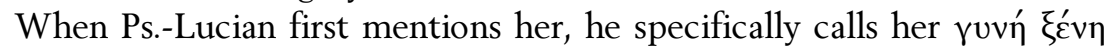

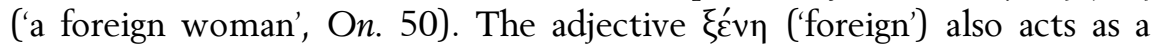
status indicator. ${ }^{16}$ With this word the woman is marked as 'other'. As Hall points out, throughout Lucius' experiences he mainly encounters familiar

\footnotetext{
${ }^{12}$ Although the function of the bestiality episode as a plot device will not be discussed except where it affects the woman's portrayal, it is important to note that the episode is directly linked to the endings in each text, driving two entirely different plot conclusions (On. 52-56; Met. 10.34.5-11.6.7).

${ }_{13}$ All translations are my own unless otherwise stated.

${ }^{14}$ LSJ s.v. үuví, I, II, IV.

${ }^{15}$ Diminutive of $\mathfrak{\eta}$ raĩs, meaning 'young girl, maiden' but also 'young female slave,

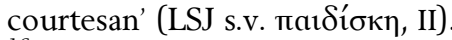

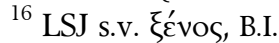


Greeks. ${ }^{17}$ The behaviour of the woman is therefore contrasted with that of the other characters. The author ensures this identification as 'other' by not making clear what foreign place the woman comes from. Any action she takes is now signalled as understandable, even if it is usually unacceptable, because foreigners, or 'others', are not the same as the reader. Therefore they are not only expected to do things differently, but they also cannot be held to the same standards as the people to whom the reader belongs, as he will interpret the passage from the assumption that he belongs to a 'superior' civilisation. What might not be acceptable in a woman of the reader's status or culture is enjoyable when the pleasure is gained at the expense of a foreigner.

In the Metamorphoses, Apuleius first identifies the woman as a matrona (Met. 10.19.3), a Latin word for a married, free-born woman. ${ }^{18}$ However, the Latin word that more nearly approximates the meaning of $\dot{\eta} \gamma u v \eta^{\prime}$ is femina. ${ }^{19}$ Femina was a general term used for 'woman' or 'female.. ${ }^{20}$ Apuleius makes extensive use of this word throughout the Metamorphoses, as well as the word mulier, used particularly of low-class women, ${ }^{21}$ as it refers to a woman with sexual experience. ${ }^{22}$ He uses the word matrona and its related adjectives far less frequently, mainly to refer to married or noble women. ${ }^{23}$ What marks Apuleius' use of matrona here as conspicuous, however, is that, while he uses it once on each other occasion to denote other women in the Metamorphoses, he uses it three times for the woman of the bestiality encounter (Met. 10.19.3, 20.1, 22.1), along with the more usual mulier (Met. 10.21.3, 22.1, 22.5) and femina (Met. 10.22.2). In addition to using a term which connotes high status relatively frequently, Apuleius on one occasion modifies the term femina with nobilis ('noble', Met. 10.22.2). Later, he even calls the woman, egregia ...

\footnotetext{
${ }^{17}$ Hall 1995:56.

18 Zimmerman 2000:263; OLD s.v. matrona, 1a \& c. See also OLD s.v. matronaliter.

${ }^{19}$ LSJ s.v. үuví, I.

${ }^{20}$ Parker 1997:48-49; OLD s.v. femina. Although femina also has connotations of respectability, Santoro L'Hoir 1992:193, 195 has shown that Apuleius uses this word both with positive and negative adjectives, to create a special language effect.

${ }^{21}$ Walters 1997:34.

${ }^{22}$ OLD s.v. mulier, 2, 3. Santoro L'Hoir 1992:188 believes that Apuleius follows the trend of using mulier for low-class women.

${ }^{23}$ See Met. 2.2.4, 23.6; 3.19.5, 23.3; 4.23.3; 7.7.2, 14.1; 9.16.3, 18.1, 23.4; 11.8.4. See OLD s.v. matrona la \& c, 2.
} 
uxor ('eminent wife', Met. 10.23.2). ${ }^{24}$ By describing such an unvirtuous woman in such noble and virtuous terms, the different identifying expressions used by Apuleius create humorous irony, in a manner not employed by Ps.-Lucian.

However, Apuleius' choices of terms create a further effect. As Zimmerman points out, "[a]lthough the connotations of virtue and gentility of the word matrona are secondary, they are frequently found in literature. ${ }^{25}$ The high birth of a matrona ensures that any sexual encounter outside marriage will result in the loss of her honour and virtue. As the episode progresses, the woman's identification as a matrona falls away and she is more often referred to as a mulier (Met. 10.21.3, 22.1, 22.5). As she takes part in the sexual encounter, her status appears to be decreasing. By referring to her as a matrona more often than he does with other women in the Metamorphoses, and then not using the word through to the end of the episode, Apuleius emphasises her status, surrounds her with the expectation of virtue, and then linguistically strips her of her status as she loses her virtue.

In addition to the identifying terms, in his first description of the matron Apuleius describes her as 'influential and wealthy' (pollens et opulens, Met. 10.19.3). ${ }^{26}$ This is in contrast to the Onos which describes the woman as beautiful and wealthy (On. 50). While beauty is often one of the defining characteristics of Greek romantic heroines, ${ }^{27}$ these heroines often become slaves in their stories without anyone suggesting that their beauty automatically indicates their high class or that it makes them ineligible for slavery. ${ }^{28}$ As to the woman's wealth, wealthy freedmen were a well-known feature of the 1 st and 2 nd centuries $\mathrm{AD}^{29}$ when this story is

24 Apuleius uses the same phrase for the condemned murderess whose punishment the ass is supposed to mete out (Met. 10.24.5). See Zimmerman 2000:292 for discussion of the ironies in this phrase.

${ }^{25}$ Zimmerman 2000:263. See Walters 1997:34.

${ }^{26}$ Hanson's 1989 translation.

${ }^{27}$ Chariton, Callirhoe 1.1.2, 14.1; 2.2.6, 3.6; 3.2.14, 17; 5.9.1; Heliod. Aeth. 1.2, 7.

${ }^{28}$ For example, Chariton, Callirhoe 1.13. See also Heliod. Aeth. 1.20, where pride, not beauty, shows Chariclea's high class to those who have kidnapped her. Although, see Chariton, Callirhoe 2.2 where Callirhoe's beauty is compared to that of a high-class woman and accords her special treatment as a slave.

29 See Hor. Sat. 2.8; Petron. Sat. 26-78 (Cena Trimalchionis) in which rich freedmen use their money to try and impress their guests with tasteless displays at a dinner. Ifie \& Thompson 1977-1978:22, 26 also point out that although wealth and rank were closely related in the time of Apuleius, wealth was not a guarantee of high status. 
believed to have been written. Although the woman in the Onos is as 'similarly well-to-do's0 as the matron in the Metamorphoses, there is no clear indication that she is a woman of high status. In addition, she is separated from the social mores of the characters in the story and the reader by her foreignness. By contrast, being influential and wealthy, in addition to being free born, suggests that the matron belongs to a family of high status, either by birth or marriage.

Lastly, unlike the Onos, Apuleius employs no modifier to suggest that the matron is foreign. If she is a local woman from Corinth, ${ }^{31}$ although this is not explicitly stated, then she forms part of the tradition of sexual iniquity for which the city was famed. ${ }^{32}$ While her behaviour is then perhaps not unexpected, her social position as high-class matrona actually defines her as 'same' in relation to the high-class, male reader. Whereas the actions of the woman in the Onos are enjoyable mainly because of her status purely as foreign and 'other', the matron is established as part of the reader's world. The purposeful degradation of a superior being or institution in society through loss of status and staining with sexual words or situations was, according to Richlin, a popular method of creating humour in Latin literature. ${ }^{33}$ However, it has long been recognised that the motives of Apuleius are far more complex than simply bringing together a 'collection of amusing stories.'.

\section{'Love' at first sight}

The passage under discussion actually begins when the woman falls into a sexual passion for the ass when she sees him on display showing off his human behaviour and decides to pay to have sex with him (On. 50; Met. 10.19.3-4). ${ }^{35}$ Immediately, the episode shows an inversion of the typical

${ }^{30}$ Zimmerman 2000:263.

31 Corinth is the venue for the show in which the ass is to appear in the Metamorphoses (Met. 10.18.1), and therefore the town in which the woman first sees him.

${ }^{32}$ Zimmerman 2000:263; Scobie 1983:108. See also Beard \& Henderson 1998:5657, 72-73 on prostitution and Aphrodite in Corinth.

33 Especially in satire and mock epic (Richlin 1992:62). The Vita Aesopi (75-76) also includes a passage in which the slave Aesop is sexually importuned and then overworked by his high-class mistress.

${ }^{34}$ Penwill 1975:49.

${ }^{35}$ Sex between a human and the ass is foreshadowed in earlier episodes of the Metamorphoses. The transforming ass wishes it were possible to use his growing penis on Photis (Met. 3.24.6). (This inability to sexually perform with a human is 
roles of the sexes, as a woman becomes the client paying for the sexual services of a 'male', placing her in the position of power and turning the ass into a submissive prostitute. However, her exact reasons for choosing the ass as a sexual partner differ in each text. Ps.-Lucian says that she fell in love with the ass, partly because of his beauty, but also because his deeds caused her to want to have intercourse with him (On. 50). Apuleius does not include a suggestion that it is the look of the ass himself that excites the woman. He says only that her constant wonder at the ass grew into 'an astonishing desire' (admirabilis cupido, Met. 10.19.3). Even if Ps.-Lucian's comment as to the ass's beauty is meant to be tongue-in-cheek, he still presents the picture of a woman who can be sexually attracted to the form of an ass. Apuleius focuses purely on the tricks of the ass, and instead presents a picture of a woman who is attracted by the unusual and the incredible. ${ }^{36}$ For Apuleius, it is the fact that the ass possesses human traits that makes him attractive to the woman.

The opening of this episode in the Metamorphoses also immediately recalls another episode in the novel. In both the Onos and the Metamorphoses, there are only two passages in which sexual acts are described. The one is the bestiality episode; the other is Lucius' sexual encounter with a slave-girl, Palaestra, in the Onos (7-10) and Photis in the Metamorphoses (2.16-17; 3.19.5-20.4). In addition to the obvious similarities between these episodes, they also mirror each other in certain details. ${ }^{37}$ However, Apuleius depicts the two encounters so that there are many more elements mirrored between them than in the Onos. In the Metamorphoses, Photis is depicted as a slave of unrestrained desire and the matron has an extreme, unrestrained lust (vaesana libido, 'mad lust', Met. 10.19.3) for the ass. In both cases, this overwhelming and easily stimulated lust leads them to take control and make the initial sexual approach to Lucius - Photis when she tucks him into bed (Met. 2.6.7) and the matron by paying for his services (Met. 10.19.4). This reflection of Photis onto the matron leads the reader to compare the behaviour of the two women, further highlighting

obviously no longer a concern for him by the time he is to have intercourse with the matron.) Later, the ass expresses his desire for Charite (Met. 4.23.3) and surreptitiously kisses her feet (Met. 6.28.2). Finally, the ass is considered a possible sex-slave for the priests (Met. 8.26).

36 This attraction is not unlike Lucius' passion for the rare and marvellous produced by magic (Met. 2.1.1), which forms part of a major theme of curiositas in the novel (see Schlam 1992:48-57; DeFilippo 1999). In Book 10 this theme is reversed when the curiositas is turned onto Lucius (Zimmerman 2000:20).

${ }^{37}$ See Zimmerman 2000:26 and Puccini-Delbey 2003:64, 81, 89, 109 for further discussion on mirroring between these two scenes in the Metamorphoses. 
the status of the latter as she is acting no differently from a slave when it comes to lust.

Apuleius also chooses to include additional commentary about the matron's passion, likening her to an asinine Pasiphae ${ }^{38}$ and specifically mentioning that she took no remedy (medela) for her lust (Met. 10.19.3). Shelton believes that the matron is judged by being likened to Pasiphae, as she is the ultimate example of a dangerous, lustful woman, ${ }^{39}$ who takes control of her sexuality away from her male relatives and chooses to have sex with a bull. By suggesting that the matron took no remedy for her lust, Apuleius is also drawing the reader's attention to the fact that her desires are inappropriate, that she knew this and chose not to restrain herself. As a matrona her high birth ensures that any sexual encounter outside marriage will result in the loss of her virtue, but she does not seem to care. This value judgement by Apuleius not only emphasises his preoccupation with status and the attendant virtue expected of women, but also shows that he is equally interested in presenting the reader with the picture of a highclass woman willingly losing her virtue and status for the lust of the lowest sexual partner, an ass.

\section{Setting the scene for seduction}

In both texts, the ass discovers the woman waiting for him. Having once again taken the initiative, she has already had her servants prepare a room and bedding for their pleasure (On. 51; Met. 10.20.2). Apuleius includes descriptions of the preparations, which do not appear in the Onos. This recalls the same careful preparations undertaken by Photis for her encounter with Lucius. However, once again status is sharply contrasted. Photis, a slave, prepares the room herself with a feast, wine, and oil for the lamp (Met. 2.11.2-3, 15.4-6). The matron has the room carefully prepared by her servants, with bedding comprising covers of gold cloth and Tyrian purple, large, soft feather pillows and the small pillows used by refined ladies (Met. 10.20.2). This description only adds to the perceived wealth of the woman as such accoutrements were the province of the rich. ${ }^{40}$

Apuleius also mentions that her servants were eunuchs (Met. 10.20.2) who hastily prepared the room and then did not delay their mistress's

\footnotetext{
38 The reference to Pasiphae specifically links this episode to the Pasiphae mime acted under Domitian which is mentioned by Martial (cf. note 3) (Schlam 1992:55; May 2006:269 n. 2).

${ }^{39}$ Shelton 2005:323-24.

${ }^{40}$ Zimmerman 2000:270.
} 
pleasure, but departed at once (Met. 10.20.3). Zimmerman suggests that the presence of eunuchs evokes the decadence of the Oriental monarchs, ${ }^{41}$ which depicts the woman as interested in 'unRoman' pleasures. This makes them unacceptable and thus exciting. Her servants' hasty preparations suggest that they have learnt from previous experience not to delay her pleasure and, therefore that she has a long history of indulging her appetites.

\section{The exposed woman}

In the Onos, after the servants leave, the woman takes control of the foreplay by lighting a lamp, stripping down and standing naked in its light in front of the ass while she anoints herself, and then him, with ointment (On. 51). In an earlier episode within the Onos, Lucius has a sexual encounter with the slave-girl Palaestra. There she strips down and, standing naked, she orders Lucius to anoint himself with ointment (On. 9). Most of the words used are identical to those used in the bestiality episode. Hall suggests that nudity strips the woman of the status associated with clothes and that stripping her clothes off levels the status between the slave and the woman. ${ }^{42}$ In addition, both scenes of seduction are set up either by the female or at her instigation. The servants are sent away and in both scenes the ass is stimulated by wine. This is one of the few mirrored elements in the Onos and the reader is obviously meant to think of the earlier episode of rambunctious sexual intercourse when reading the bestiality episode. Apuleius treats this section differently, but still with the intent of creating mirroring elements. He, too, mentions each woman stripping (Met. 2.17.1; 10.21.1), so Hall's suggestion as to the statuslevelling effect of nudity can also be applied to the Metamorphoses. The nakedness of both Photis and the matron once again highlights the fact that the matron is now no better than a slave. On the other hand, by choosing to display her naked body, as the slave-girls purposely do to inflame Lucius' ardour, the woman in both texts can also be interpreted as further taking control of the sex act by enticing the ass with her nakedness.

Apuleius also mentions both Photis and the matron being responsible for their scenes of seduction, the servants being sent away and the ass being stimulated by wine (Met. 2.15.4-16.7; 10.20.2-21.4). However, he includes mention of how the light of candles brightened the night's darkness (Met. 10.20.3). Here the reader is intended to think, not just of

\footnotetext{
${ }^{41}$ Zimmerman 2000:269.

${ }^{42}$ Hall 1995:55.
} 
an earlier episode of sexual activity with Photis, but a reference made in the story of Cupid and Psyche, where the narrator notes that lamps were invented by a lover to ensure that he could continue to enjoy his pleasures even at night (Met. 5.23.5). While Ps.-Lucian is intent on having the reader think of the woman purely in the context of sexual intercourse, Apuleius' differing emphasis suggests that he wants his reader to be thinking of what trouble is caused for, and by, those who want to participate in unrestrained and illicit sexual activity. When the link between the Photis episode and the bestiality episode is read together with the reference to the light, the reader is not only reminded of Photis' sexual encounter with Lucius, but also that she was the reason he was turned into an ass. The sexuality of the matron is therefore shaded with a hint of danger towards men, namely Lucius. ${ }^{43}$

Despite the attention the matron focuses on her body, Apuleius also portrays her as concerned for her privacy and secrecy, which is not at issue in the Onos. Ps.-Lucian notes that the servants of the woman, after readying the room, settle somewhere close at hand outside the room (On. 51). Apuleius, on the other hand, says that the servants closed the bedroom door and went away (Met. 10.20.3). In addition, the woman in the Metamorphoses is later careful not to be seen coming or going from her rendezvous with the ass (Met. 10.22.5). In contrast, the woman in the Onos later invites Lucius in his human form into her home (On. 56). A reputation for respectability is not important to the woman in the Onos; on the other hand, the matron wants to ensure the protection of the appearance of her virtue in the Metamorphoses. ${ }^{44}$ This care for her reputation once again affirms her high status. This is further borne out when Apuleius later has the ass specifically note that the high status of the matron automatically eliminated her as a candidate for public bestial intercourse (Met. 10.23.2). He also says that the master was forced to acquire a condemned woman who had already lost all status as no other woman could be had for the show, not even for a high price. He makes a further point of noting that the crimes of the condemned woman were so

43 The woman's lust for an ass makes her indirectly dangerous to Lucius, as her desire inspires the murderess's punishment of bestial rape by the ass in a spectacle (Met. 10.23.1-2). Lucius will be in both social and physical danger. He will be humiliated by becoming part of a public spectacle, suffer the contagion of exposure to a polluted murderess, as well as run the risk of becoming food for the wild beasts in the amphitheatre (Met. 10.29.1, 34.5).

44 Langlands suggests that the appearance of female virtue (pudicitia) in the Metamorphoses must always be suspect as it is often used to cover up adultery (2006:230-31; see also 233). 
bad that her original punishment of being thrown to the beasts was less than she deserved, except that no more worthy punishment could be devised (Met. 10.28.5). This not only highlights the status of the matron, it also suggests that she would be on a par with a condemned murderess who is worthy of bestial rape if her acts became public knowledge.

\section{Getting it up?}

One of the elaborations that Apuleius may have made to the scene of foreplay is actually to be found in the margin of one of the MSS of Apuleius' Metamorphoses. This has become known as the spurcum additamentum, ${ }^{45}$ a corrupted piece of text which seems to belong directly after the description of the ass's anointment with oil by the woman (Met. 10.21.1). It tells in detail how the woman anoints and cleans the genitals of the ass, from which he achieves an erection. The authenticity of this additamentum has been the subject of much debate. ${ }^{46}$ However, the possibility that it may be authentic means that it requires closer scrutiny as part of this episode. The matron is described as rather expertly bringing about the ass's erection. Lytle suggests the entire passage is similar to ancient descriptions of how to stimulate an ass to ensure breeding takes place with a mare. ${ }^{47}$ The additamentum also says that the woman became aroused herself at the sight of the erect penis of the ass, and that, at the sight, she said the small delay for the preparation of the room had been a year to her. The additamentum, therefore, depicts the woman as sexually experienced, proactive and lustful, which is consistent with the depiction of her sexuality in the rest of the text. However, the explicit descriptions of sexual organs and the mechanics of the sexual process which form part of the additamentum are alien to Apuleius' suggestive, sophisticated style of euphemism and double meaning when describing sex and the human body, which makes the authenticity of this piece extremely suspect. ${ }^{48}$

\footnotetext{
45 See Zimmerman 2000:433-34; Zimmerman 2012:xxiii-xxv. For texts and translations of the spurcum additamentum, see Zimmerman 2000:434; Hunink 2006:278-80; Zimmerman 2012:xxiii. For a commentary, see Mariotti 1956:23246.

${ }^{46}$ See Zimmerman 2000:434-39 and Carver 2007:67-71 for summaries of the different arguments, both for and against the authenticity of the spurcum additamentum. See Zimmerman 2012:xxiv-xxv for the latest conclusions.

${ }^{47}$ Lytle 2003:357.

${ }^{48}$ See Hunink 2006:276; May 2009:73.
} 


\section{Words of love}

The matron goes on to kiss the ass and speak to him affectionately (On. 51; Met. 10.21.2-3). In contrast to the Onos, the ass in the Metamorphoses describes the kisses given by the woman, saying that they are not those in any way connected to a whorehouse, but are 'pure and sincere' (pura atque sincera, Met. 10.21.2). He quotes her words, describing them as 'most flattering speeches' (blandissimi adfatus, Met. 10.21.2). He also says that they are words used by women to stimulate others and show their own feelings. Some scholars have suggested that the inclusion of the description of the matron's kisses and her words injects a note of tenderness. ${ }^{49}$ However, by contrasting the matron with a prostitute, the ass's description is one that a man might use to boast of the status of the woman he is capable of attracting, as well as the quality of the sex he is getting. In addition, the words of the matron are actually a parody of themes from Latin love poetry. ${ }^{50}$ Her words "I love you" and "I desire you" and "I choose you alone" and "Already I cannot live without you"' ('Amo' et 'Cupio' et 'Te solum diligo' et 'Sine te iam vivere nequeo', Met. 10.21.3) mock the declarations of fidelity and eternal love by poets, ${ }^{51}$ especially since the speaker is paying for the temporary services of her animal beloved. The fact that the words are spoken by a woman, the usual, and often fickle, recipient of such sentiments, ${ }^{52}$ further mocks the genre by placing her in the active position of lover. This undermines the romantic sincerity of the matron's declarations. The only other words the matron is quoted as saying, during penetration, further undermine any notion of tenderness. "I have you" she said, "I have you, my little dove, my sparrow." ('Teneo te,' inquit 'teneo, meum palumbulum, meum passerem.' Met. 10.22.3) recalling Catullus 2 and 3 which refer to a female lover and her pet sparrow. However, the sparrow is often considered to be a metaphor for the poet's penis. ${ }^{53}$ Lastly, the verbal encouragement of the matron, so far from exhibiting tenderness, is actually suggestive of the words and tone

\footnotetext{
${ }^{49}$ Shumate 1996:126; Finkelpearl 1998:155.

${ }^{50}$ Zimmerman 2000:277.

51 For example, Catull. 109; Prop. 1.4, 12, 19; 2.17, 20; Tib. 1.6. See Lyne 1980:65-67. See also Zimmerman 2000:277 for examples of these themes from Greek novels.

${ }^{52}$ For example, Catull. 8, 11, 58, 70; Prop. 1.6, 15; 2.5, 8, 9, 16; 3.25; Tib. 1.6.

53 Dyson Hejduk 2011:255-57. See also Zimmerman 2000:286 on the lasciviousness of doves and sparrows in Latin literature. By using bird names the reader is also again reminded of Photis who failed to turn Lucius into a bird (Hallett \& Hindermann 2014:313).
} 
a woman might use to gently exhort a recalcitrant animal, ${ }^{54}$ or, to paraphrase the ass, to encourage a lover to greater feats of sexual vigour. This in turn is also a typical theme in the love poetry of Ovid. ${ }^{55}$ The matron therefore seems to be quite experienced in stimulating a sexual partner (or even an animal?). Her virtue also obviously means nothing to her, as without compunction or shame, she encourages the ass. The tone is not tender and focuses on the sexual experience of the matron.

Among all the words Apuleius uses to embellish this scene, there is one particular set, used by Ps.-Lucian, which he does not employ. When describing the words of the woman, Ps.-Lucian says that she spoke 'as if' (oîa, On. 51) to a man. While this is no doubt meant to be ironic because, of course, the ass is a man in disguise, Ps.-Lucian also seems to be highlighting the relationship between animality and humanity when it comes to sexual appetites. He has already shown the animality of the woman by depicting her as being attracted to the ass's form. Despite her attempts to normalise the encounter with the traditional foreplay formulas, she is still having intercourse with an ass, and can only treat him 'like' a human. The contrast in the Onos is therefore between human and animal. Apuleius' different treatment of the foreplay instead turns the contrast into one between low-class prostitution and high-class unchastity.

\section{Positioning the ass}

In the Onos, the ass worries about how to mount the woman as he has had no experience having sexual intercourse, either as an ass or with an ass (On. 51). This suggests that he was considering the traditional animal mating position, in which a female is on all fours and is mounted from behind by the male. Although the woman later lies down beside him 'as if

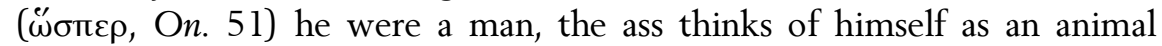
rather than a human. Ps.-Lucian is therefore emphasising the animality of the human inside the ass. Apuleius, by contrast, emphasises the human traits of the ass. In the Metamorphoses, the woman takes him by the halter and makes him lie down as he had learned to do (quo didiceram, 'which I had learned', Met. 10.21.3). The reader is thus reminded that earlier, when the ass's trainer was teaching him to act as a man to entertain people, he was taught to lie on a couch on his 'elbow', in a typical dining posture (Met. 10.17.3). If he is lying on his side, then a very likely position of the

\footnotetext{
${ }^{54}$ See Lytle 2003:355, also 355 n. 15.

${ }^{55}$ For example, Ov. Ars am. 3.795-96; Am. 2.19.17; 3.7.11-12, 14.25; Hallett \& Hindermann 2014:313.
} 
matron is on her side with her back to him, with one leg raised to facilitate penetration. This position is well attested in Roman $\operatorname{art}^{56}$ and literature. ${ }^{57}$ Apuleius does not make it perfectly clear if the back-to-face, half-reclined position is the one they adopt or if they are face to face, but whatever the case, it is very different from the typical position on all fours supposedly adopted by women for intercourse with an animal in ancient literature. ${ }^{58}$

By emphasising the animality of the human inside the ass, Ps.-Lucian in turn highlights the inability of the woman to raise their encounter to the level of human-to-human sex. Although she once more tries to treat the ass like a human, her lust for his animal appearance and his animality, both in form and in mind, immerse her in true unrestrained bestial sex, despite her efforts to keep control by taking charge of the act. Apuleius on the other hand, not only emphasises the human traits of the ass, he also makes no mention here of the ass having intercourse with other animals, ${ }^{59}$ and he draws no specific attention to the human/animal duality. Consequently, unlike the woman in the Onos who is attracted to, and having sex with, an unusual animal that just happens to be a human, the woman in the Metamorphoses is having bestial intercourse with an animal who is practically a human, as far as she is concerned. ${ }^{60}$

\section{Constructing the sexualised body}

In both texts the ass is eager for intercourse, but fearful (On. 51; Met. 10.22.1-2). In the Onos, in addition to his worries that he does not know how to mount the woman as an ass, the ass also fears that she may be too small, that he will consequently damage her in the encounter and be forced to pay the penalty as her murderer. The emphasis here is entirely on how the encounter affects the ass. Apuleius too has the ass express such fears, but in a completely different way, which places the emphasis

\footnotetext{
${ }^{56}$ In art a man and woman are often depicted reclining on a couch. The woman reaches behind her with her arm around the man's head and they are about to kiss. At the same time the man lifts the leg of the woman and is about to penetrate her. See Clarke 1998:168, fig. 60; Clarke 2003:44-45, figs. 18 and 167.

57 Ovid notes of sexual positions that a simple, and least laborious, one is when the woman 'lies half-reclined on her right side' (iacet in dextrum semisupina latus, Ov. Ars am. 3.788).

${ }^{58}$ For example, Bacchyl. 26 Snell-Maehler; Apollod. Bibl. 3.8-11; Juv. 6.334.

${ }^{59}$ However, the ass does show an interest in mating with mares earlier when he receives his reward for helping to rescue Charite (Met. 7.16.2).

60 See Shumate 1996:124 who suggests that the sex with the matron is one of Lucius' most human characteristics as an ass.
} 
on the woman instead. He highlights the woman's status by mentioning it twice (Met. 10.22.1, 22.2), ${ }^{61}$ but Apuleius also has the ass ask in rhetorical style how he, with the ugly body of an ass, could mount, embrace and kiss such a delicate matron (Met. 10.22.1). In expressing this, Apuleius has the ass compare his body and mouth with those of this high-born woman, so that the reader is presented with a picture of her sexualised body. He had already specifically mentioned her body parts when he noted her breasts as she stripped off her clothing at the beginning of their encounter (Met. 10.21.1). Now he mentions her soft, delicate body in comparison to an ass's hard hoofs and her lips to an ass's large, misshapen mouth (Met. 10.22.1).

This disparity in their appearances leads to the ass's fear that she will be too small to contain his huge organ (Met. 10.22.1). During Lucius' encounter with Photis, Apuleius draws attention to the pubes of Photis in a subtle way. He describes Photis as holding her hand in front of her pubic area to produce an image of a modest Venus. This only heightens Lucius' ardour, as she is 'purposely shadowing rather than modestly hiding it' (obumbrans de industria quam tegens verecundia, Met. 2.17.2). ${ }^{62}$ By having Lucius wonder if he will be too big for her, Apuleius, using the same technique, draws attention to the matron's genital area without describing it (Met. 10.22.1). He produces the same effect in the reader that Photis' action produces in Lucius. By giving the matron a body, he titillates the reader. In addition, as Schlam points out, by expressing the fear concerning the size of his organ, the ass actually underscores the woman's later capacity to accept a large penis. ${ }^{63}$ Apuleius also includes a line here which Ps.-Lucian does not use until the end of the passage. Ps.-Lucian mentions that the woman was so ready for sex that she stayed the whole night (On. 51). Apuleius includes part of this sentiment at this point, having the ass say instead that despite the fact that the woman was so ready for sex, he did not know if she would be big enough (Met. 10.22.1). By using this line here, the emphasis is again placed on the insatiability of the woman.

The veiled reference to the matron's vagina, her earlier display of her body, as well as her desire for privacy lends a voyeuristic tone to the episode, which is totally absent from the Onos. This is further borne out by the authors' differing treatments of the ass's encounter with the condemned murderess. In the Onos, the murderess is instructed to make

\footnotetext{
${ }^{61}$ See the section headed 'Identifying and describing the female' (above).

${ }^{62}$ Hanson's 1989 translation. See Slater 1998:20, 24 on eroticism and control of the gaze in this scene.

${ }^{63}$ Schlam 1992:73.
} 
advances towards and to fondle the ass (On. 52), so that he will repeat his sexual performance with her in the arena. The ass's interactions with both women are intended to be openly erotic. The ass's interaction with the murderess in the Metamorphoses has no erotic element. Only the horror of her murderous actions and the fact that the ass will be polluted by association are noted (Met. 10.29.1). The eroticism of the act of bestiality is therefore reserved for the episode featuring the matron, and the secrecy surrounding the act means that the reader becomes a voyeur.

\section{Sex, unassuaged lust, and animals}

The fears of the ass turn out to be groundless in both texts when the woman is able to accommodate his entire penis (On. 51; Met. 10.22.3). Nevertheless, the ass tries to withdraw to spare her his large size (Met. 10.22.4). She, however, will not allow him to withdraw and actually follows his penis when he tries. In the Onos, when the ass realises that if he wants to ensure her pleasure he cannot gently draw away, he is able to take control of the act and do hard service without fear. In the Metamorphoses, when the ass loses his fear, he goes to the other extreme of believing that 'something is lacking in me to fulfil her lust' (deesse mihi aliquid ad supplendam eius libidinem, Met. 10.22.4). Although the woman in the Onos needs to be serviced hard, she can be satisfied by sex with an ass. This becomes even more evident when she later throws the human Lucius out of her house, after she discovers that his transformation has left him without the ass's genitalia that originally satisfied her (On. 56). However, for the woman in the Metamorphoses, even sex with an ass seems barely able to satisfy her, leaving the ass out of control of the situation as he tries to meet her demands.

In both texts, in the same scene, the ass mentions the myth of Pasiphae and the bull. In the Onos, the ass declares that he considers himself to be no worse than Pasiphae's lover (On. 51). The ass is equating himself with the bull of myth, again emphasising his animality and minimising the role and importance of the woman. However, in Apuleius, the ass says that the Minotaur's mother might have had reason to seek a bull as a lover (Met. 10.22.4). Here, as Zimmerman points out, the emphasis changes completely, as it is now the woman who is compared to the human of the myth. ${ }^{64}$ Pasiphae's act was induced by the gods, but Apuleius does not mention this, suggesting only that Pasiphae might have sought out the bull because she had an insatiable need for pleasure that only the bull could fulfil, thus

${ }^{64}$ Zimmerman 2000:264-65. 
casting the matron in the same light. This treatment of the mention of the Pasiphae myth also links with Apuleius' additional mention of it earlier in the passage at Met. 10.19.3. It can be seen that there again Apuleius focuses on the woman's links to the myth, not the ass's, and thereby continually draws parallels that depict the woman as insatiably lustful and dangerous to male regulation as she takes control of her own desires.

As the episode ends in each text, the woman spends the whole night and then negotiates to return again for another encounter (On. 52; Met. 10.22.5). This scene is almost identical in both texts. Yet in the light of the portrayal of each woman, in the Onos her night-long stay and negotiated return can be read as proof of her sexual satisfaction with the ass. On the other hand, the woman in the Metamorphoses stays the night and wishes to return because her appetites cannot be satisfied.

\section{Conclusion}

The portrayal of the woman and her sexuality in the bestiality episode in the Metamorphoses can now be seen to be in contrast with the Onos. Ps.Lucian places his emphasis on the raw animal passions and animal traits of the human. He uses the act of bestiality to comment on the bestial nature of humans. For him bestiality becomes an expected expression of human sexuality when left unrestrained because of foreign sensibilities and notions. This becomes a cautionary tale, since, without the ability to have sexual restraint, all humans are shown to really be animals no matter how they may try and cling to their humanity. ${ }^{65}$ Although the woman initiates the event and takes control of the ass and the act at first, in the end her bestial lusts lead her to lose control to the ass.

Apuleius places a completely different emphasis on the story. $\mathrm{He}$ focuses far more on the woman in the story than Ps.-Lucian does. He describes her body, her sexual acts and appetites, and brings in strong mirror elements between the matron and the other female character who engages in sex in the novel, Photis. By doing so, he highlights the insatiable and unusual sexual appetites and willing loss of virtue of the high class and therefore supposedly virtuous woman. He leaves the bestial aspects of the act to speak for themselves. Instead, by emphasising these other aspects of the woman and her sexuality, he explores a very human lust - that of a bored, jaded, wealthy, high-class woman for a new and unusual way to

65 The conclusions of Apuleian scholars as to the meanings of the bestiality episode in the Metamorphoses can more accurately be seen to be applied to the Onos. 
fulfil her insatiable appetites. ${ }^{66}$ This examination shows, therefore, that the matron is not actually that different from the other women in the novel whose female sexual insatiability leads them to seek sexual appeasement outside of marriage. She therefore forms part of the discourse on female sexual nature which permeates the novel.

From this study several further conclusions can be made as to the role the woman in the bestiality episode plays. On the one hand, there is the obvious entertainment value. Firstly, the reader is titillated by reading a description of a woman engaged in a sexual act. The pleasure to be found in watching acts of bestiality was not unknown from Roman spectacles. ${ }^{67}$ The reader can also indulge in the illicit pleasure of being the unseen viewer, looking at a high-class and oblivious woman, whose sex acts are not supposed to be for public edification. Secondly, there is the sadistic pleasure of watching a woman of high class lose her virtue, which would, if her acts were made public in the novel, plunge her down into the lowest status, as Apuleius infers. For the ancient male readership at least, the acts of this woman could be read as reinforcing a feeling of male superiority and self-restraint in contrast with such unrestrained female lust.

However, on the other hand, the same situation which delights also produces horror. Firstly, a married woman of wealth and status chooses not to try to restrain her urges, but instead to defile herself, indulging in an illicit act of the most debased form. Secondly, she further defiles herself by exposing her body and acting like a slave. Thirdly, and perhaps most frighteningly for the contemporary male readership, she actively uses her position of wealth and privilege to obtain her desires and thereby takes control of the deployment of her sexuality away from her male relatives, while employing a degree of stealth to preserve her position so that she can use it again. Indeed, she controls the entire situation throughout. Although she is insatiably lustful, she is always in control of how she wants to try and fulfil her desires, choosing her partner, the manner of foreplay, and even the degree of penetration. At each point, she guides the actions of the submissive male ass, never completely giving herself over to his control. The connection Apuleius creates between the reader and the woman, by calling her a matrona, means that the reader therefore experiences the simultaneous horror and feeling of powerlessness which comes from knowing that the act of bestiality could have involved one of his own female relatives, which might lead to his own disgrace.

\footnotetext{
${ }^{66}$ Puccini-Delbey 2003:111 also notes this motivation for the matron's actions.

${ }^{67}$ Suetonius (Ner. 12) and Martial (Spect. 5) both mention acts of bestiality in the amphitheatre.
} 
The matron therefore has several major roles in addition to the superficial one she plays in projecting bestial characteristics onto other, especially female, characters. This interpretation of the purposes of the matron in the bestiality episode has implications for other studies related to the Metamorphoses. Firstly, the analysis of the matron and her sexuality suggests that the sexual activities of the other women in the novel can be read as issues of female desire and their control of their own sexuality. Secondly, the lack of emphasis on the human/animal duality of the woman encourages a re-appraisal of Lucius in this passage. Is he more or less human due to the emphasis on the humanity of his sexual partner? Is he more or less male due to the sexual control of his female partner? Lastly, the dual feelings of sexual titillation and horror the matron induces ultimately lead to feelings of unease and dislocation in the reader. This can be read as a foreshadowing of the rupture in the narrative tone of the first ten books triggered by the intervention of Isis.

\section{Bibliography}

Beard, M. \& Henderson, J. 1998. 'With this body I thee worship: sacred prostitution in antiquity.' In M. Wyke (ed.), Gender and the Body in the Ancient Mediterranean, 56-79. Oxford: Blackwell Publishers.

Carver, R.H.F. 2007. The Protean Ass: The Metamorphoses of Apuleius from Antiquity to the Renaissance. Oxford: Oxford University Press.

Clarke, J.R. 1998. Looking at Lovemaking: Constructions of Sexuality in Roman Art I00 B.C.-A.D. 250. Berkeley, Los Angeles \& London: University of California Press.

Clarke, J.R. 2003. Roman Sex IOO BC-AD 250. New York: Harry N. Abrams, Inc., Publishers.

Cooper, G. 1980. 'Sexual and ethical reversal in Apuleius: the Metamorphoses as anti-epic.' In C. Deroux (ed.), Studies in Latin Literature and Roman History, Vol. 2:436-466. Brussels: Latomus.

Cueva, E.P. \& Byrne, S.N. (edd.). 2014. A Companion to the Ancient Novel. Malden, Mass., Oxford \& Chichester: Wiley-Blackwell.

DeFilippo, J. 1999. 'Curiositas and the Platonism of Apuleius' Golden Ass.' In S.J. Harrison (ed.), Oxford Readings in the Roman Novel, 269-289. Oxford: Oxford University Press.

Dyson Hejduk, J.T. 2011. 'The Lesbia poems.' In M.B. Skinner (ed.), A Companion to Catullus, 254-275. Malden, Mass., Oxford \& Chichester: Wiley Blackwell. 
Finkelpearl, E.D. 1998. Metamorphosis of Language in Apuleius: A Study of Allusion in the Novel. Ann Arbor, Michigan: The University of Michigan Press.

Frangoulidis, S. 2001. Roles and Performances in Apuleius' Metamorphoses. Stuttgart \& Weimar: Verlag J.B. Metzler.

Garson, R.W. 1977-1978. 'The faces of love in Apuleius' Metamorphoses.' Museum Africum 6:37-42.

Hall, E. 1995. 'The ass with double vision: politicising an ancient Greek novel.' In D. Margolies \& M. Joannou (edd.), Heart of the Heartless World: Essays in Cultural Resistance in Memory of Margot Heinemann, 47-59. London \& Boulder: Pluto Press.

Hallett, J.P. \& Hindermann, J. 2014. 'Roman elegy and the Roman novel.' In Cueva \& Byrne 2014:300-316.

Hallett, J.P. \& Skinner, M.B. (edd.). 1997. Roman Sexualities. Princeton: Princeton University Press.

Hanson, J.A. (transl.) 1989. Apuleius: Metamorphoses. Vols 1-2. London \& Cambridge, Mass.: Harvard University Press.

Hunink, V. 2006. 'The "spurcum additamentum" (Apul. Met. 10,21) once again.' In W.H. Keulen, R.R. Nauta \& S. Panayotakis (edd.), Lectiones Scrupulosae: Essays on the Text and Interpretation of Apuleius' Metamorphoses in Honor of Maaike Zimmerman. Ancient Narrative. Supplementum 6:266-280. Groningen: Barkhuis Publishing \& Groningen University Library.

Ifie, J.E. \& Thompson, L.A. 1977-1978. 'Rank, social status and esteem in Apuleius.' Museum Africum 6:21-36.

James, P. 2014. 'Apuleius' Metamorphoses: A hybrid text?' In Cueva \& Byrne 2014:317-329.

Langlands, R. 2006. Sexual Morality in Ancient Rome. Cambridge: Cambridge University Press.

Lyne, R.O.A.M. 1980. The Latin Love Poets: From Catullus to Horace. Oxford: Clarendon Press.

Lytle, E. 2003. 'Apuleius' Metamorphoses and the Spurcum Additamentum (10.21).' CPh 98.4:349-365.

MacLeod, M.D. (transl.) 1967. Lucian. Vol. 8. London \& Cambridge, Mass.: Harvard University Press.

Mariotti, S. 1956. 'Lo spurcum additamentum ad Apul. Met. 10,21.' SIFC 27.8:229-250.

Mason, H.J. 1978. 'Fabula graecanica: Apuleius and his Greek sources.' In B.L. Hijmans Jr. \& R.Th. van der Paardt (edd.), Aspects of Apuleius' Golden Ass, 1-15. Groningen: Bouma's Boekhuis. 
May, R. 2006. Apuleius and Drama: The Ass on Stage. Oxford: Oxford University Press.

May, R. 2009. 'An ass from Oxyrhynchus: P.Oxy. LXX.4762, Loukios of Patrae and the Milesian Tales.' Ancient Narrative 8:59-83.

Parker, H.N. 1997. 'The teratogenic grid.' In Hallett \& Skinner 1997:47-65.

Penwill, J.L. 1975. 'Slavish pleasures and profitless curiosity: fall and redemption in Apuleius' Metamorphoses.' Ramus 4.1:49-82.

Perry, B.E. 1967. The Ancient Romances: A Literary-Historical Account of their Origins. Berkeley \& Los Angeles, California: University of California Press.

Puccini-Delbey, G. 2003. Amour et désir dans les Metamorphoses d'Apulée. Brussels: Éditions Latomus.

Richlin, A. 1992. The Garden of Priapus: Sexuality and Aggression in Roman Humor. Revised ed. New York \& Oxford: Oxford University Press.

Robson, J. 1997. 'Bestiality and bestial rape in Greek myth.' In S. Deacy \& K. Pearce (edd.), Rape in Antiquity: Sexual Violence in the Greek and Roman Worlds, 65-96. London: Duckworth.

Santoro L'Hoir, F. 1992. The Rhetoric of Gender Terms: 'Man', 'Woman', and the Portrayal of Character in Latin Prose. Leiden, New York \& Köln: E.J. Brill.

Schlam, C.C. 1992. The Metamorphoses of Apuleius: On Making an Ass of Oneself. Chapel Hill, North Carolina \& London: The University of North Carolina Press.

Scobie, A. 1983. Apuleius and Folklore. London: The Folklore Society.

Shelton, J. 2005. 'Putting women in their place: gender, species, and hierarchy in Apuleius' Metamorphoses.' In W.W. Batstone \& G. Tissol (edd.), Defining Genre and Gender in Latin Literature: Essays Presented to William S. Anderson on his Seventy-Fifth Birthday, 301-329. New York \& Oxford: Peter Lang.

Shumate, N. 1996. Crisis and Conversion in Apuleius' Metamorphoses. Ann Arbor, Michigan: The University of Michigan Press.

Slater, N.W. 1998. 'Passion and petrification: the gaze in Apuleius' CPh 93:18-48.

Sullivan, J.P. (transl.). 1989, 2008. 'Pseudo-Lucian: the ass.' In B.P. Reardon (ed.), Collected Ancient Greek Novels, 589-618. Berkeley, Los Angeles \& London: University of California Press.

Van Thiel, H. 1971. Der Eselroman, Band 1: Untersuchungen; Band 2: Synoptische Ausgabe. Zetemata 54.1, 54.2. Munich: Beck.

Walters, J. 1997. 'Invading the Roman body: manliness and impenetrability in Roman thought.' In Hallett \& Skinner 1997:29-53. 
Zimmerman, M. 2000. Apuleius Madaurensis: Metamorphoses, Book X: Text, Introduction and Commentary. Groningen: Egbert Forsten.

Zimmerman, M. (ed.) 2012. Apulei Metamorphoseon Libri XI. Oxford: Oxford University Press.

susan.haskins@up.ac.za 